\title{
Engaging in Testimonio as a walk through el laberinto (the labyrinth) of higher education: Releasing, receiving and returning to the field with deeper purpose
}

\author{
Farima Pour-Khorshid, ${ }^{1}$ Margarita Machado-Casas, ${ }^{2}$ Katherine Talati, ${ }^{3}$ Diana Gomez ${ }^{4}$ \\ \& Guillermo Castillo ${ }^{5}$
}

Fecha de recepción: 6 de septiembre de 2019

Fecha de aceptación: 13 de noviembre de 2019

\begin{abstract}
Latinx first-generation college graduates often experience a myriad of structural, emotional, financial and academic barriers while navigating higher education as undergraduate and graduate students and later, if they become faculty members. While many studies have documented these struggles within the field, the political, methodological and pedagogical praxis of testimonio has been used to reflect on and document these struggles in ways that give the authors agency in retelling and reclaiming their experiences of marginalization and resistance. In this paper, the authors build on the metaphor of a labyrinth to describe how higher education can often feel similar to a maze-like path to navigate, yet, the spiritual and reflective practice of labyrinth- walking involves three stages of soul development which can also be experienced through testimonio: releasing, receiving and returning to oneself
\end{abstract}

\section{Keywords:}

Higher education, faculty of color, students of color, resilience, testimonio, social justice.

${ }^{1}$ University of San Francisco. ORCID: 0000-0002-9576-8631

2 San Diego State University. ORCID: 0000-0003-2051-2444

${ }^{3}$ A\&M San Antonio. Número. Correo electrónico: espinozaka@utexas.edu. ORCID: 0000-0001-6939-3509

${ }^{4}$ San Diego State University. ORCID: 0000-0001-8936-414X

${ }^{5}$ San Diego State University. ORCID: 0000-0002-7945-4499 


\section{Introduction}

1 he number of Latinx ${ }^{6}$ students in higher education continues to be low across the US, which has led to the emergence of the Hispanic Serving Institutions (HSI) intended to recruit, admit and support their success within universities (Santiago \& Andrade, 2010).

Rodriguez and Osegueras found that, in higher education, Latinx students struggle with a plethora of institutional and interpersonal barriers such as "financial aid challenges, retention, (low) expectations, and mentorship options from faculty and other leadership who recognize their specific challenges, strengths, and potential to thrive as college-level students" (2015, p. 2).

Rodríguez, Mosqueda, Nava and Conchas (2013) argue that there are many issues that impact the opportunity landscape available to Latinx students, and that transformation is needed across the educational pipeline. While Hispanic Serving Institutions (HSIs) are intentionally designed to diversify undergraduate and graduate student bodies across universities in the country, there continues to be a diversity gap when it concerns university faculty. The National Center for Education Statistics reported the racial demographics of higher education faculty which remains disproportionately white regardless of gender:

Of all full-time faculty in degree-granting postsecondary institutions in fall 2017, 41 percent were White males; 35 percent were White females; 6 percent were Asian/Pacific Islander males; 5 percent were Asian/ Pacific Islander females; and 3 percent each were Black males, Black females, Hispanic males, and Hispanic females (McFarland, Hussar, Zhang, Wang, Wang, Hein et al., 2019, p. 228)

The racial demographics of higher education institutions is important to consider in relation to the academic and social experiences of students of color. The presence and pedagogies of a faculty of color have positive implications on the success and retention of students of color (Umbach, 2006). Hurtardo, Ruiz \& Whang (2012) specifically address how microaggressions? experienced by students and faculty of color also affect campus climate and lead to higher rates of attrition. When people of color are subjected to constant microaggressions on their college campuses the entire culture of the school impacts individuals' sense of emotional safety and wellbeing. When considering the power dynamics related to People of Color (POC) thriving as tenure-track faculty in higher education, the relationship between the higher education institution and individuals matters (Mawdsley, 1999).

\section{The necessity to diversify student and faculty racial demographics in higher education}

The faculty of color who have overcome institutional barriers, to make it into academia are still faced with "a state of de facto racial and gender segregation" where they are "stratified along institutional type, academic ranks, and departments" (Delgado Bernal \& Villalpando, 2002, p. 170).

Astin, Antonio, Cress \& Astin found that, "at least $60 \%$ or more of the faculty of color reported 'somewhat extensive' to 'extensive' stress about

\footnotetext{
${ }^{6}$ We utilize the term Latinx as a gender-neutral alternative to "Hispanic" and "Latino/a" which is grounded in the politics of race, ethnicity and gender (Morales, 2018). The term Latinx intentionally reframes Anglo- American paradigms of Latinidad by also including Afro-Latinx, biracial Latinx, gender noncomforming Latinx, and other groups that are often at the margins of dominant Latino/a identities.

7 The term microaggression refers to (a) subtle verbal and non-verbal insults/assaults directed toward People of Color, often carried out automatically or unconsciously; (b) layered insults/assaults, based on one's race, gender, class, sexuality, language, immigration status, phenotype, accent, or name; and (c) cumulative insults/assaults that take their toll on People of Color. In isolation, racial microaggressions may not have much meaning or impact; however, as repeated slights, the effects can be profound (Kohli \& Solórzano, 2012, as cited in Kohli, 2008, p. 13).
} 
the review/promotion process compared to only $44 \%$ of white faculty" (1997, p. 81). RhoadesCatanach and Stout (2000) noted that tenure-track decisions have long-term consequences not only for the institution but also for the candidate. Urrieta, Méndez and Rodríguez's (2015) study found that Latinx faculty members navigating the tenure and promotion process experienced it as "a tool of fear", a nebulous process, like "a moving target", receiving tenure gained limited forms of respect but not full membership, and Latina/o faculty's supervivencia (Galvan, 2011, p. 552-557) helped them to cope with the negative issues and environments they sometimes felt they were in (p. 1150).

Guarino and Borden (2017) relied on a large national survey of faculty members at more than 140 institutions and found large discrepancies between faculty service loads reporting that women carry a significantly heavier load of service compared to men in academia, even when controlling for rank, race/ethnicity, and field or department. When tenure track faculty are expected to excel in publishing and teaching, while also contributing internal service (e.g., departmental/university labor related to faculty governance, evaluation, promotion, student admissions, scholarships, program supervision, etcetera) as well as external service (e.g., service to the profession outside of the university and to local, state, regional, national, international communities, etcetera) the discrepancies in workload make a huge difference in terms of faculty experience (Guarino \& Borden, 2017). However, other studies have pointed to the difficulties that women of color particularly face in higher education, compared to their white female counterparts due to multiple marginality that they experience and embody (Turner, 2002; Rains, 1999).

\section{The role of mentorship in navigating higher education}

Mentorship matters for students and faculty of color when navigating higher education. Traditionally, mentorship in doctoral education has been described as a relationship established to support professional growth that does not typically extend beyond the institutional academic setting (Anderson \& Shore, 2008; Rich \& Davis, 2007; Forehand, 2008; Hu, Thomas \& Lance, 2008; Paglis, Green \& Bauer, 2006). Scholarship in this area emphasizes the mentorship role in the induction of a mentee into the academic community, providing them with necessary tools to network and engage with other scholars in the field. The depth of mentoring varies and may not always serve the mentee in effective ways, for example, faculty members who are not awarded tenure express disdain for being insufficiently mentored through the process (Fish, 2002).

Conventional and professional forms of mentorship do not always adequately meet the needs of students and faculty of color if and when there is a cultural and social disconnect rooted in power and privilege, which leads to people of color creating their own mentoring support groups (Ek, Cerecer, Quijadada Cerecer, Alanís \& Rodríguez, 2010). More holistic approaches to mentoring should address the whole person which can allow for mentees to assuage feelings of isolation, and emotional trauma (Ponjuan, 2011). Mentorship plays a critical role particularly in the experiences of students of color and faculty in higher education, therefore findings ways for students and faculty to connect to people who can serve as mentors is critical in the experience and a measure students and faculty may have.

\section{Purpose of the study}

In this article, we rely on the methodological practice of testimonio (Bernal, Burciaga \& Carmona, 2017; Fuentes \& Pérez, 2016; Pour-Khorshid, 2016) to explore the ways in which a range of Latinx people navigating higher education across various positionalities (graduate student, assistant professor, full professor and department chair) 
experienced challenges and resiliency throughout their higher education journeys. The experience of writing and sharing their testimonios led to spiritual and emotional clarity when reflecting back on and reclaiming their stories. More specifically, we draw on our own experiences as five self-identified Latinx people (four cisgender ${ }^{8}$ women and one cisgender male), that embody a range of positionalities as we reflect on navigating different milestones in academia. The authors share the ways in which they had to negotiate the struggles of being Latinx in academia through their respective roles which informed their purpose, practice and future directions within the field. We build on Machado-Casas, Ruiz \& Cantú's metaphor of navigating higher education as a "laberinto", a labyrinth, which can make students and faculty of color feel "an overpowering sense of loss and lack of direction as they enter [...] the labyrinth of academic structures, a place that can be dark, lonely, and without much direction" (Machado-Casas, Ruiz \& Cantú, 2013, p. 4).

While a labyrinth is essentially a maze-like path that can be difficult to walk through, when the practice of walking through is taken up as a spiritual practice, the experience becomes a meditative act to get more in touch with one's soul and deeper existential purpose (Artress, 1996). We posit that the practice of testimonio writing offers students and faculty of color in higher education a spiritually grounded labyrinth walk-like experience that allows the writer space to engage in the three stages of a physical labyrinth walk: releasing, receiving and returning (García \& Curry-Rodríguez, 2000). In essence, we argue that engaging with critical race, feminist theory and praxis like testimonio serve as a healing-entered practice that also offers future generations paths of possibility to navigate higher education at any level.

\section{Conceptual frame: Engaging in testimonio as a metaphorical walk through the laberinto of higher education}

In this article we borrow from Ruiz \& Machado-Casas the notion of the laberinto of higher education to conceptualize the experiences that students and faculty of color have when attempting to navigate higher education:

\begin{abstract}
A laberinto contains places that are complicated and uncertain. When you enter a laberinto you don't really know the way or how you will get to the end. There is some uncertainty as to which way to go, or if the path that you have chosen is the "right" way. As one goes through the laberinto one feels overwhelmed because of the uncertainty of where to go. The one thing we do know about this laberinto is that one needs to figure out the road(s) that lead to the exit (Ruiz \& MachadoCasas, 2013, p. 52).
\end{abstract}

While Ruiz \& Machado-Casas (2013) use this metaphor to describe the overwhelming uncertainty within the complicated path of higher education, we revisit this concept with a renewed lens with which to understand walking through this metaphorical labyrinth through the process of writing one's testimonio. To elaborate, the view of walking a labyrinth is in fact complicated and filled with maze-like barriers just like higher education is, however, when walking a labyrinth with spiritual grounding and connectedness, just like engaging in testimonio, the experience can feel quite the contrary. For example, according to Sandor and Froman, walking a labyrinth as a spiritual and healing centered practice involves three particular phases in one's experiences:

${ }^{8}$ We utilize the term cisgender to describe a person who identifies as the gender that they were assigned at birth. 
The first phase, releasing, occurs during the walk to the center at a normal walking speed. Walkers are encouraged to empty their minds; repeat a chant, word, or prayer; pose a problem to be solved; or recall a dream to reflect on. When in the center, walkers engage in receiving and may sit or stand while inviting an opening to personal healing, solace, connection, renewal, and wholeness. The third phase of the walk, returning, involves retracing one's steps in the opposite direction. Walkers return to the day-to-day world with each step, and while doing this often experience a change of energy in mind, body, and spirit. The intent of the labyrinth walk is to evoke physiological, affective, and spiritual outcomes similar to a sitting meditation (Sandor and Froman, 2006, p. 104).

As such, engaging in testimonio is a deeply personal and spiritual act and experience when processing and reclaiming our struggles as people of color navigating oppression in the world. In the following section, we describe testimonio and our methodological approach to this study.

\section{Methodology}

We engage in a narrative research rooted in testimonio as our methodological approach to explore the experiences of navigating higher education from the vantage points of four women and one man whom all identify as Latinx. Testimonio has served as a powerful tool for women identified as Chicanas/ Latinas to share their stories about navigating marginalization and more importantly, to stand in solidarity with others who share similar experiences and struggles (Moraga \& Anzaldúa, 1981; Anzaldúa,
1987; Castillo, 1994; Elenes, 2000; Flores \& Garcia, 2009; Saldivar-Hull, 2000).

Testimonio offers women of color a liberating space to reflect on their lived experiences and positionalities in the world through critical race and feminist theory and reclaim their stories with agency (The Latina Feminist Group, 2001). Perez Huber and Cueva assert that, "testimonio allows Chicana/Latina researchers to document and inscribe into existence a social witness account reflective of collective experiences, political injustices, and human struggles that are often erased by dominant discourses" (Pérez \& (ueva, 2012, p. 393).

While testimonio has been developed for and by Chicana/Latina women, it has also been taken up by people of color more broadly in order to reflect on, share and witness one another's racialized, gendered and intersectional struggles and lived experiences as a means of consciousness-raising, healing and solidarity (Pour-Khorshid, 2018a, 2018b). Stories of resilience and resistance to subordination often emerge from testimonio research which lead to transformative experiences for participants. The very process of testimoniando is homemade theory for the generation of knowledge that is often delegitimized in institutional spaces (Nuñez-Janes \& Robledo, 2009). In keeping with testimonio practice, these authors integrate non-standard English and Spanish words within their manuscript and throughout their narratives, because in doing so, it allows their authentic voices to highlight how a language choice also embodies a political stance in centering non-dominant identities and cultures as a form of reclamation.

This study, therefore, allows for each of us, as Latinx identified scholars in the realm of academia, to reflect on and heal from our own experiences navigating higher education through the act of testifying about our resilience in the midst of navigating structural oppression. We engage in this labor of love with the hope that other Latinx students 
and faculty can not only relate to our stories, but also find inspiration to engage in a similar process as a form of resistance and sustainability in the field and in the world more broadly.

\section{Participants}

The participants in this study are self-identified Latinx individuals who range in experience and roles in their professional career within higher education. Katherine is a mixed-race Iranian and Mexican assistant professor at an HSI in her first year as a tenure-track faculty in the US South. Farima is a mixed-race Iranian and Nicaraguan assistant professor in her second year at a private Jesuit university in California. Margarita Machado-Casas is a full professor and administrator for a bilingual education department at a Hispanic Serving Institution (HSI) in California. Guillermo Castillo is a graduate student, university instructor and also coordinates a teacher pipeline program for students of color with Margarita at the same HSI. Diana is a graduate student and instructor at an HSI in California. In the following section, participants share their testimonios related to their experiences navigating their respective locales and roles within higher education. Beginning with Katherine's "I ate beans and rice in grad school too': Overcoming the pain of microaggressions in a doctoral program"; following with Farima's, "From research to 'me-search': Finding purpose in my pain and power"; next, Guillermo's "Fighting gatekeeping practices: Pathways as laberintos in higher education"; then, Diana with "Dismantling invisible labels while creating visible pathways"; and Lastly, Margarita with "The revolution is real and continues: The fight for institutional access for students of color".

\section{OUR TESTIMONIOS: NAVIGATING HIGHER EDUCATION WHILE LATINX}

\section{"I ate beans and rice in grad school too": Overcoming the pain of microaggressions in a doctoral program}

Katherine Talati

As a student of color at a Tier I institution, I almost immediately felt a sense of alienation, like I was in a foreign place. Hailing from a Hispanic Serving Institution for my bachelor's and master's degrees, my initial conceptualizations of college life were completely different from what I experienced on my first few days in my doctoral program. Little did I know these feelings of being an outsider were only the beginning. This narrative serves as a testimonio, my truth, to the experiences I was subjected to and how I overcame such obstacles. Communities of color have bonded together to examine the discriminatory and exclusionary practices they are oftentimes subjected to through the use of a microaggressions perspective (Sue, Capodilupo, Torino, Bucceri, Holder, Nadal and Esquilin, 2007). The field of microaggressions originally derived from an understanding of racism encountered on a daily basis by people of color. Smith, Mao and Desphande explain that "microaggressions refer to the daily indignities, invalidations, and slights that are experienced by people of color (even when the perpetrators are not aware of having done so)" (2015, p. 127).

\section{La verdad: Understanding the important role of} hermandad in times of trouble

It was the spring of 2015 and I was finishing my second year of course work and I was excited to enter into the next phase of my graduate studies. I was not a traditional graduate student, as I continued working as an elementary bilingual teacher out of not only financial necessities, but also passion. As a result, one of my professors (a white woman) became concerned about my dedication to the doctoral program. She 
went as far as requesting a meeting with me towards the end of the semester. I remember walking into her office and feeling a huge knot in my throat. She began by mentioning that she felt it odd that I was not forthcoming with the information that I was working additional hours while attending school. I told her that I did not feel comfortable discussing my personal struggles with her because I did not feel like she knew me. I told her that I did not feel comfortable having this conversation because I knew of other doctoral students who worked outside of school too. I asked her if they had been questioned, or if they were going to be in the same manner, and she said no. I asked her why she was concerned about me, and she told me that she did not want me to lose momentum. I told her that I felt like I had balance in my school, work, and life and that I did not fear falling behind.

Then it happened, she began talking about her own experience in grad school. She told me: "I know what it's like to be in grad school. I ate beans and rice during my entire program. Those were my strict vegetarian years." I was shocked, I could not believe these words came out of this woman's mouth. I could not understand it, was she trying to elicit sympathy from me when in my own experience, I have always eaten rice and beans, coming from a modest Mexican-American household? That's what we ate because of our own limited means -not because we were vegetarians. These were the unexpressed thoughts in my head, and I told her that my choice to work was not only for myself, but that I have always been there to help my family financially, too. She concluded the meeting by stating she just wanted to make sure I was making good financial choices and that she wanted me to find a good balance in what I was doing, and again, she did not want to see me lose momentum. I then told her again that I did not feel like I was losing momentum, that I felt like I was growing academically. I shared that I had attended my first national conference, that I had gotten A's in all of my classes and that I was working hard this semester to maintain my high GPA.

\section{Findings: The $f$, from failure to future}

Then it happened, after checking my final grades, I saw that she had given me an $X$, which indicates an incomplete course. I emailed her to find out why, and she said that she had found that my final paper was not up to par. I discussed this incident and had a further email exchange with other professors in the department, where I explained that I felt this professor was abusing her power and using this entire situation to reprimand me for the previous events that had taken place this semester.

For the first time in my educational career I felt like a complete failure. I remember walking out of the education building utterly shaken. I was too embarrassed to tell my family and friends. I did the only thing I knew I could do - I called my professor from my undergrad and master's program.

Dr. MMC had always been my mentor, however this was the first time she literally became my ángel de la guardia, my guardian angel. It was through this hourlong conversation that I learned what microaggressions were, and that what had happened to me was not my fault. More importantly, I learned that I was not alone and that although she had no power at the university I attended, she possessed the poder de hermandad. Bettez, Lopez and Machado-Casas (2009) explain that women of color come together to form a sisterhood of support to navigate struggles, they define this as hermandad, the Spanish word for "sisterhood." Their research focuses on how faculty women of color bond together to support each other.

Bettez, Lopez and Machado-Casas (2009) established that hermandad is a relationship created and cultivated by women of color in academia to sustain them throughout their struggles. The guidance that Dr. MMC provided to me during this tumultuous time showed me what hermandad relationship was in academia. They explain,

It is a way to recognize that as women of color in academia we are here together, 
and each other's cause is a shared cause for voice, visibility, sustainability, and empowerment in academia. It is the legacy of the struggle of those who came before and paved the way for us, which we will leave here in this world as Latina women (Bettez, Lopez and MachadoCasas, 2009, p. 60-61).

Within days I received emails and contacts from Latina professors in Texas, Arizona, and California, all wanting to help me in this struggle. Dr. MMC used her connections and together we navigated this new terrain. These women took the time to read timelines of events that occurred, and more importantly shared their wisdom with me. I was even invited to share my experiences in grad school on a panel at a national conference. In the end this professor was able to label me and awarded me my first $F$ on my transcript.

The mentorship, confianza, and hermandad I received from Dr. MMC provided me with the tools and helped me develop my own conocimiento about what had really happened to me. Anzaldúa (1987) imparts her wisdom about conocimiento and teaches us that through the traumatic experiences we encounter, we develop conocimientos to help us reflect on the events we have endured. Once we have taken the necessary time to evaluate what has happened, we can then begin to heal.

The hermandad developed between Dr. MMC and I evolved over a decade. At the time I experienced this trauma I was not prepared nor equipped with the necessary tools to begin this healing process. Already a tenured professor, Dr. MMC knew how to navigate spaces and experiences that were new to me. She shared her own stories of struggle in her doctoral program with me, so that I knew that I was neither the first nor the last person this type of microaggression would happen to.

To this day the $F$ still haunts me and triggers flashbacks from this entire experience. I went on to complete my doctoral degree from a different program within the same university. Again, Dr. MMC stepped in and used her connections to put me in contact with a new advisor. However, it was a constant struggle within me to continue. Days on end of having to engage in selftalk and affirmation that I belonged in this space, that I was deserving and that I could finish this journey.

\section{Conclusion: Sobrevivencia and moving forward}

Now that I have finished my doctoral degree, I have had to reposition the $\mathrm{F}$ I received on my transcript. In some ways I now view it as a badge of honor for what I had to endure to make it to where I am today. Solórzano's (2010) microaggressions model indicates that the ways students respond to these traumatic encounters is of utmost importance. Furthermore, I have learned it serves as a constant reminder, always present, but as a motivating mechanism now to help and serve others. Yúdice (1991) initially presented the testimonios as a method for individuals to use their experiences and talk back about their own survival. Prieto describes these feelings as "sobrevivencia, esperanza, amor, coraje, cariño, y conocimiento" (2009, p. 134). MachadoCasas et al. (2013) metaphorically conceptualize the process graduate students take in navigating new spaces as a "laberinto". The experiences I had at a Tier I institution included dark and isolated spaces where I felt I did not belong. In the beginning I felt like I was walking through this maze with a blindfold over my eyes, walking into dead ends at every turn. García \& Curry-Rodríguez (2000) explain that through spiritually grounding ourselves, we engage in a labyrinth walk that allows us to release, receive, and return to ourselves. I was able to release the pain that I associated with what happened to me because of situations that were beyond my control. The help I received through mentorship and the hermandad with Dr. MMC allowed me to continue to grow academically. The greatest gift I obtained was the ability to return to myself and to push forward. Through this encounter in my doctoral program I learned and used all of these tools to make it to the end. 
Sobrevivencia to hold my head up every day and continue on. Esperanza in knowing that I could still dream of the future and that this event did not define me as a student. Coraje because I knew what was done to me was truly an injustice and hurt for those who had experienced similar treatment before and after me. Amor from the love that was shared with me through the mentorship and hermandad with Dr. MMC and other Latina professors who helped me. Conocimiento, the awakening of the knowledge that microaggressions exist and we must defend ourselves against them.

\section{From research to "me-search": Finding purpose in my pain and power}

Farima Pour-Khorshid

Two years ago, I left elementary teaching after a decade of service in my community for a tenure-track professorship and I continue to identify and serve as a grassroots local and national educator-organizer. I am currently in my second year as an assistant professor. Since the age of five I have navigated educational systems that have always been perpetual reproduction sites of structural violence and harm since colonization. I know this because I've studied the history of US education, but also because I've survived schooling as a student and as an educator of color navigating inequitable policies and school practices, white-washed curricula, racist peers, colleagues and administrators as well as culturally biased assessment metrics for most of my life. I have experienced first-hand how education institutions, regardless of what level, lack fundamental services, resources, and support for both students and educators who are the most marginalized within them. As a PhD student, I began to research how teachers of color are impacted within the profession and in doing so, I began to come across some of my own experiences reflected within the literature and research that I read. I became engulfed in trying to understand the myriad issues impacting Black, Indigenous and People of Color (BIPOC) via schooling because the more I read, the more I was able to name and understand my own experiences. I wrestled with the complexities of feeling validation that my struggles were documented and simultaneously feeling deep sadness that these realities were and still are so common.

I struggled teaching kindergarten throughout my six-year PhD student journey because I became increasingly frustrated with the unhealthy norms of productivity expected and normalized in both elementary and university institutions, especially in the face of trauma impacting students spanning all ages. In my kindergarten class, my precious five-yearold students carried the weight of poverty, the violence of deportations, of navigating several foster homes, homeless shelters and Child Protective Services, of trying to understand why their parents/loved ones were incarcerated, or how to stay safe in the midst of domestic violence or state sanctioned violence, or how to be healthy while lacking access to healthcare, or any of the endless ways in which the symptoms of structural violence lead to constant fear, stress, anxiety, depression and grief. Meanwhile, within the same week, I'd teach undergraduate sections where some of the most brilliant university students of color were having to live in their cars, survive by eating canned foods while sending money to their family and simultaneously struggling with their own mental health, trauma, impostor syndrome, ${ }^{9}$ racial microaggressions, discrimination and countless systemic barriers to accessing resources, all while trying to stay afloat

9 Pauline Clance and Suzanne Imes coined the term "impostor syndrome" in 1978 to describe the phenomenon of high achieving individuals who believe that they do not deserve their success/role believing their achievement/placement is based on luck or timing, not merit. Individuals who struggle with impostor syndrome personalize and internalize mistakes and failures to confirm the feeling that they do not belong (Sherman, 2013). "Impostor syndrome" refers to the internal experiences of individuals who struggle with fitting into academic spaces that were not typically created for individuals of color; see Cope-Watson \& Betts (2010). 
academically. These undergraduate students were once kindergarteners that carried similar stressors in their childhoods too. It became overwhelming to witness some of my own struggles in the lives of young children and adults, and to be tasked with being their beacon of light through the darkness that they/ we were navigating. The reality is that these dynamics have never been foreign to me -in fact, because they're so familiar I was and still am often triggered by my students' realities. All of these struggles disproportionately impact marginalized people from communities like mine, where the cycles of poverty and the symptoms of structural oppression repeat from generation to generation. Yet still we rise, with all of the brilliance and resilience that we've inherited from our ancestors, family and communities.

My last year in the PhD program I had to take a leave of absence as a student and also as an adjunct instructor for various reasons, so I did not have access to health insurance because I simply could not afford it. During this time, a close mentor, comrade and friend of mine died from suicide, my mother's health declined and she was in and out of the hospital, my Iranian grandmother passed away, I was watching social media videos of loved ones in Nicaragua fighting for their lives as students and elders protesting the Ortega regime were tortured and murdered daily, and I was falling apart as I tried desperately to finish my dissertation and the kindergarten school year. There were moments when I was terrified of being left alone simply because my depression felt so dark and yet, I needed to be alone since writing often required isolation. Luckily, I had close grad school friends that looked out for me, I had family members that stepped in to support (one of which was my cousin who is also a co-author of this piece), and I had a graduate advisor that had my back through every traumatic event that I experienced. My advisor treated me as if I were part of her family from the very beginning of my PhD journey. My baby brother passed away at age 25, two months before I started my PhD program. I vividly remember needing to walk out of classes or meetings to find refuge in my advisor as she comforted me while I wept in her office grieving, navigating microaggressions, impostor syndrome and struggling to stay afloat in a program that I felt completely disconnected from. Her ability to see and treat me like a human being, and to support me emotionally and academically through so many recurring hardships played a significant role in my sustainability. All of the individuals who supported me emotionally cared about me and saw my humanity rather than pushing and expecting productivity like others in academia did.

The toxic culture of production in higher education often made me feel inferior, disposable and worthless.

The reality is that I have always had to find people and spaces outside of school institutions to help me navigate my mental health struggles, trauma, institutional harm and barriers. As a daughter, sister, aunt and friend, I experienced a lot of shame about my struggles because I didn't want my loved ones to worry about me but I also didn't want to confirm my own negative self-talk within those relationships. As a teacher and graduate student, I felt the same shame because there was never time or space for people of color to feel human, to feel safe to express grief or to engage in self or collective care within education institutions. I have always felt like I was expected to be "professional" by leaving the "drama at the door" which really meant leaving my trauma at the door. I was expected to conform and to be desensitized to the ways I witnessed and was expected to participate in the pathologizing of people of color of all ages. Professionalism, from my experience navigating education institutions, has also

${ }^{10}$ The term respectability politics was articulated by Evelyn Brooks Higginbotham (1993) in her book, Righteous Discontent: The Women's Movement in the Black Baptist Church, 1880-1920, to describe how in the context of Black American history, some Black people consciously hid or set aside cultural practices and ways of being that were thought to be looked down upon by the dominant society and culture as a way to integrate into it. 
been code for deeply rooted respectability politics ${ }^{10}$ that often reinforce colonial, capitalist and assimilationist logics, which continue to oppress marginalized people. The more I reflect on my experiences as an educator and student of color, the more I realize how spirit murdering (Love, 2019) is a byproduct of navigating education institutions.

There are punitive practices to penalize people of color who resist dehumanization and there are rewards for our conformity. Throughout my journey I've come to learn that these kinds of expectations and dynamics are colonial in nature and go against all of my ancestors' dreams for me and the generations to come after me. Gloria Anzaldúa taught me that "awareness of our situation must come before inner changes, which in turn come before changes in society. Nothing happens in the 'real' world unless it first happens in the images in our heads" (2009, p. 310). Navigating higher education forced me to confront my own internalized oppression, which was a pivotal epiphany in my journey toward critical consciousness. I learned to master the guise of professionalism by repressing my pain and performing in ways that felt dehumanizing and spirit-draining. For years I maneuvered within and through professional spaces at the expense of sharing my truths and showing up fully as myself, exacerbating impostor syndrome on all fronts of my teaching and graduate student journeys. However, through my graduate studies, I sought out critical mentors who helped me to understand how professional development, at its core, focuses on preparing educators to more effectively take up standards, assessments, curricula and strategies that maintain white supremacy, ${ }^{11}$ not dismantle or aspire beyond it. These relationships were crucial to repurposing my role and responsibility within this field.

Navigating higher education gave me the language and theory to understand that even with the various ways that I've been impacted by ideological, interpersonal, internalized and institutional forms of oppression, I simultaneously have a lot of privilege as a first-generation college graduate, a privilege that many people of color in the US are/were not afforded. This privilege is what pushes me to stray away from what is expected of me as a "professional" in the field and instead, utilize my privilege to enact change by committing to the liberation and self-determination of people of color. This kind of political commitment will be what I embody as I mentor other future educators of color now that I am a professor in teacher education, and I hope that will also impact the means in which my students and other educators who know me or have read my scholarship will teach to future generations along the way.

It was in and through my grassroots social justice educator collectives and organizing spaces that I became inspired to cultivate the kind of learning conditions for my students that I needed when I was younger and that I still need now as a woman of color: a humanizing space to feel seen, heard, valued, loved and empowered. These elements nurture conditions for envisioning and aspiring toward liberating possibilities within the realm of education and beyond. For these reasons and more, my doctoral research and "mesearch" is rooted in what l've theorized as critical and healing-centered racial affinity spaces. This came from my ethnographic case study of the first racial affinity group that I co-founded with two other women of color comrades within the Teachers 4 Social Justice (T4SJ) grassroots organization. We named the group H.E.L.L.A. Educators of Color. The name came out of a conversation regarding how the term hella proclaims an identity and sense of belonging to the Bay Area and yet, in higher education spaces, the word can simultaneously be perceived as unprofessional. I felt that it would be fitting to center our linguistic capital and Bay Area cultural

${ }^{11}$ I utilize the term white supremacy to describe a) the "socio-political economic system of domination based on racial categories that benefit those defined and perceived as White. This system rests on the historical and current accumulation of structural power that privileges, centralizes, and elevates White people as a group"; and b) the assumed superiority of individuals and ways of being that are perceived or identified as White and hence, the societal standard (Sensoy \& DiAngelo, 2017). 
ties by reclaiming the word for our group. H.E.L.L.A. is the acronym for the group's ideological and pedagogical commitments to the following learning tenets: healing, empowerment, love, liberation and action. Considering that only $17 \%$ of people in the teaching profession identify as teachers of color, these stats make the name of our group ironic, at times depressing, but ever inspiring. There are not "hella" teachers of color in the quantifiable sense but there absolutely are H.E.L.L.A. teachers of color when it comes to the political stances that we take in and out of the classroom. H.E.L.L.A. educators of color was conceptualized to represent people of color in the field of education who do not ascribe to the dominant culture and who actively resist colonial, neoliberal and white supremacist ideologies that are embedded in the policies, pedagogies and practices paraded as commonsensical approaches to improving education. The educators of color who believe that true education should aim toward self-actualization, determination and world change. The ones who believe that their own learning and development should not be sanitized, standardized or corporatized professional development but instead, a kind of humanizing development centered in healing, empowerment, love, liberation, and action.

So, in essence, my research has been and continues to be "me-search", since I believe that my purpose in this field is to inspire other people of color navigating higher education through sharing my own healing journey and the collective healing that manifests when we create spaces for ourselves to heal collectively. I believe this "loveolutionary" endeavor serves as a catalyst to disrupt these toxic cycles of oppression and reimagine new ways of being in academia and in the world.

\section{Fighting gatekeeping practices: Pathways as laberintos in higher education}

Guillermo Castillo

Pathways have always been a part of my life. I remember vividly my mother, who had to learn how to cook at age 11 after her father's death, answering the phone and trying to communicate using her limited English with Mr. Rucker, who was my water polo coach, a tall lanky redhead who was finishing his credential, had a baby and had a part-time teaching position at my high school. With his broken Spanish, I could hear him tell my mother I could go to college and potentially get a scholarship. My mom had a few exchanges with him, hanged up and turned to my dad. "Dice el maestro que Memo puede ir al colegio" (The teacher says Memo can attend college). A few weeks later Mr. Rucker walked me to the counseling center and gave me threecourse catalogs of potential institutions I could attend. Without me realizing it at the time, my life had changed forever. Unknowingly, that was the beginning of my first pathway. Mr. Rucker met with my counselor, moved me from consumer math to pre-algebra, and connected me with the upward bound program and helped set up school visits. He used his institutional knowledge to help me navigate through the college application process and ensured I was part of programs which supported my path. My undergraduate work was a struggle, I was not academically prepared for the rigors of academia. I lacked confidence and the academic preparation to excel, I simply survived. Years later, I graduated from Cal State San Bernardino and became a teacher at my former middle school. Determined to make a difference, as I saw on a daily basis the needs of my students and the importance of using access and privilege to help them get ahead. I began coaching the water polo team and built a competitive and successful program.

The local paper, the San Diego Union-Tribune, became aware of our team's success and featured my work on the front page of the sports section. I shared my story, specifically about Mr. Rucker. A few days later, Mr. Rucker showed up to practice with the article in hand. "Guillermo, I never knew how much of an impact I had on your life", he said. And I responded, "Mr. Rucker, without your help, I would not have attended college nor would I be the first person in my family to graduate, you changed my life." For those of us who do not 
grow up with privilege, we often need a transcender, a life changer with access who opens up doors and possibilities; as better stated by Freire, "knowledge emerges only through invention and re-invention, through the restless, impatient, continuing, hopeful inquiry human beings pursue in the world, with the world, and with each other" (2008, p. 244)

My coach, who was struggling through life, did something to change my life, not because it was in his job description, but because it was the right thing to do. He used his understanding of the system, empathy, and compassion to reinforce and connect me with structures and support mechanism to help me pathway into college. This is only one example that illustrates why I am passionate about creating pathways and providing access to students from minoritized and marginalized communities. For me, this is not only a passion but a call of duty and obligation. As stated by Margaret Wheatley, "there is no power for change greater than a community discovering what it cares about" (cit. en Kaufman \& Raphael, 1984, p. 19). Discovering that I can be an agent of change in the life of others and use education as a tool for access and a counter story against oppressive systems has led me to develop and support pathways. I was lucky to have Mr. Rucker in my life, but many people are not as fortunate. As I navigated life these last 25 years in education, I realized pathways are not only beneficial but essential.

The first pathway I developed was as a high school coach. I realized that to be successful in water polo, students had to start early, especially in South San Diego where many youths do not have access to pools or swimming lessons. The structure was not there for low-income students to become water polo players, they had no access to help them compete with the resources available at high-income communities. As a result, I started a youth program, teaching students how to swim at an early age in order to give them a competitive edge -this led to the creation of my first pathway. Paulo Freire is quoted, "no one is fully-formed: it is through self-experience in the world that we become who we are" (Freire, 2000, p. 129). Pathways provide opportunities for all to potentially be successful, it is not left to chance. My central focus remains working with teacher pathways through a research orientedlens, one that specifically looks at how to support individuals from disadvantaged backgrounds to enter pathway programs. Many members of our community are marginalized from opportunities by institutions which serve as "gatekeepers" with established policies which consistently limit access. Using a mixed methods approach, more research has to be done in educational pathways mechanisms which have been successful in providing students access to higher education and professionalization and changes or structures which need to be put in place to support the development of educational and career pathways. At the core of my personal and professional goals are social justice, equity, and access.

The experience of teaching high school, middle school and elementary English language learners has afforded me a perspective of our educational system which has informed my thinking around pathways. For many of my students, language and access were closely related. Thinking of my kindergarten students accessing language specifically in a Spanish immersion program at Longfellow Elementary School reinforced the importance of access.

Students who spoke only English were provided structure and programs which helped them learn Spanish, another example of a pathway. The opportunity provided to 5-year-olds to acquire a second language will open doors throughout their life. The passage of Proposition 58 and the elimination of Proposition 227 has provided our communities with an opportunity to engage our immigrants through language. As a bilingual Mexican fronterizo immigrant, my commitment to social justice and change through educational pathways access can serve as a way to fight institutionalized racism, discrimination, and inequities which can, in turn, change our state, country, and society. As better stated by Paulo Freire: 
[...] Education either functions as an instrument which is used to facilitate integration of the younger generation into the logic of the present system and bring about conformity or it becomes the practice of freedom, the means by which men and women deal critically and creatively with reality and discover how to participate in the transformation of their world (Freire, 2000, p. 129).

Education is the number one equalizer and needs to be accessible to those communities who have been marginalized through policies, economics or historical factors. My father, an adult immigrant who as a child struggled to have enough to eat, shared with a crackling voice after my graduation, "el trabajo me escogió a mí, pero tú con educación, puedes escoger tu trabajo" (work chose me, but with an education, you can choose your work). I am privileged now, and what I do with that privilege reflects on my character. Being of service and opening doors for those community members who are struggling or lacking the confidence to move forward is an obligation I assume with determination and vigor. We need to take an interest to change our educational system to provide our communities with sustainable mechanisms which promote social awareness and justice for communities which have struggled to be heard and supported.

I have been developing delineated teacher pathways for Mini-Corps tutors, who are former migrant and first-generation college students, classified employees, and other populations which have struggled or are challenged with entering and completing a credential program. My work revolves around "gatekeepers" which have traditionally left aspiring teachers at the steps of the gate. I have come to understand how entrance exams have limited access, especially to second language learners. I have established online mechanisms to support with writing, math and reading comprehension for those aspiring to enter a credential program. I have also established partnerships with over 7 counties, 3 community colleges, 2 universities and over 10 districts in the establishment of pathways from high school to PhD. These partnerships have provided opportunities to learn from each other, identifying best practices and avoid working in silos.

I have been collaborating with the Dual Language and English Learner Education Department by costarting the first online bilingual credential program in all the CSUs. This program was tailored to support the nontraditional student which works full time, has a family and had challenges navigating the system. I am eager to expand my learning on the theoretical frameworks and how these can inform and strengthen theoretical assumptions to help evaluate my work critically. The theoretical framework will help me research existing knowledge guided by a relevant theory and look at a basis for a hypothesis and choice of research methods. Articulating the theoretical assumptions of a research study will force me to address questions of why and how. Now, I begin a new stage of my life as a doctoral student. I'm nervous but also excited and I think about all the students I work with -and without a doubt I see myself in them. The laberinto continues. I'm releasing the knowledge I gained after working toward pipeline programs to help students of color and non-traditional students. I realize that a new challenge begins in this laberinto called higher education. I realize that, at my age, and this stage of my life, I'm a non-traditional student who will rely on the mentorship of those who have come before me -I will be receiving. I have realized that it is a cycle of growth and we all must contribute to it if we really want change and social justice. We move from mentoring to being mentored in a constant state of flux, that is always returning. 


\section{Dismantling invisible labels while creating visible pathways}

Diana Gomez

Invisible labels have been a part of my life in education. My earliest memories of school had always been positive. I had caring teachers, although I never really connected with a single educator. I attended my neighborhood school which still is in Southeast San Diego from preschool to sixth grade where I enjoyed reading, writing and listening to stories. I had no idea that I was in a class designated for English learners and that I would be labeled as such for a number of years. That invisible label reinforced a certain stereotype about my ethnicity and my culture. A track had already been designed for me, unbeknownst to me, I was already treated as someone whose language and culture was seen as a deficit. You did not have to tell me that I was different from others, my classroom felt different. As Gershen Kaufman states in his work, "identity is the essential core of who we are as individuals, the conscious experience of the self-inside" (Kaufman \& Raphael, 1984, p. 35). The goal was to take away my home language so that I would learn English, the language of power. Despite their best efforts, I was able to retain my language as I constantly served as a translator and interpreter for my parents and grandmother. I learned from home about my heritage and identity and outside my home, I learned to hide my culture and identity. As better stated by Gloria Anzaldúa in The New Mestiza when speaking about language and culture as a site of terrorism and oppression, "like all people, we perceive the version of reality that our culture communicates. Like others having or living in more than one culture, we get multiple, often opposing messages. The coming together of two self-consistent but habitually incomparable frames of reference causes un choque, a cultural collision" (1987, p. ) I was taught from a very scripted curriculum that did not allow for flexibility in addressing my needs as a student. There was no mention of my identity or culture and there was certainly no celebrating who I was and where I came from. There must not have been any heroes or contributions made by people like me. As I progressed through my schooling I became more aware that I was at a disadvantage and set up for failure from the very beginning. I lived in a stage of Nepantla in between the system that had already set me and my classmates to fail, and sadly, I witnessed many failures. My language and culture had been tamed, oppressed, and tracked. I was on a particular path for students that spoke Spanish, just like me and that was seen as a problem that had to be dealt with. What better way than to move away from my core culture to the other side of the tracks. I was encouraged to leave my neighborhood when I reached middle school and high school and was eventually bussed 30 minutes away from my home to be integrated with youth that was vastly different from me. As noted by Murillo (2002), Latino is often seen as "the problem". One that can only be addressed by a removal that leads to complete alienation from one's culture and directs to assimilation. In the process, I experienced a culture shock as I felt more pressure than ever to blend into a community that was so unattainable for me in a number of ways, specifically economically and socially. Leaving me feeling like an imposter just the same way Maya Angelou described it, within an educational system that was supposed to protect me. That lonely feeling of non-belonging and inadequacy. During the day, I experienced ocean views from the windows of my classrooms and then by dismissal time I was transported back to where I belonged, literally the undesirable south side of town. My community was plagued with gangs, constant police raids, and the ever-present drug deals. It was as if I was living in two worlds and did not fit into either. Nepantla was my reality, and I was a walking contradiction ready to find belonging. For the duration of my entire $\mathrm{K}-12$ career, my teachers did not look like me, speak like me or exposed me to curriculum that connected with me as a Mexican girl. This was normal to me. 
I am the daughter of immigrant parents who also happen to have been teenage parents. Along with these dynamics, there were issues of abuse, alcoholism, domestic violence, and cultural roles that were to be adhered to. Being initially undocumented, inexperienced and with highly limited English skills, my parents were confined to very few options for employment. My parents insisted that the sole opportunities for a better life would only be attained with an education. My mother became a waitress and my father played the guitar at the local Mexican restaurant. The pay was minimal, but all of our basic needs were provided for. They both worked demanding hours and were always too exhausted to attend school events, much less to check our homework or read to us. I have often heard that parents such as mine do not care about education and the truth is that they are just like other undocumented working people, too preoccupied with keeping a roof over their children's head and food on the table, that attending back to school night is not their priority. Unable to explain social and economic inequities to my teachers, my parents were framed as "uncaring". They too were tracked. However, the reality at home was different, my parents instilled the value of education and always used themselves as examples of missed opportunities and access. My father is one of thirteen siblings from rural Mexico and had always lived in poverty. He attended school up to second grade and then had to begin working to help support the rest of the family. My mother who was born in Sinaloa, she is the youngest of six and had the unique opportunity to finish middle school. Eventually, my maternal grandmother moved into our home and took on the role of mother for everyone in the household. She served as a symbol of strength that would guide us with her consejos (advice) even after her death. I remember that although I was not a child that received academic support at home, I had to figure out a way to maintain the best grades and always make my parents proud. They always wanted my sister and me to succeed and believed education was the only way to make it in this country. The track that was set out for us at home could not be more different from the one set out for us in school. Interestingly enough, no one ever monitored my academic progress, yet I was able to navigate the educational system. I did not end up in jail or, like many of my childhood friends, a teenage mother, even though all odds had been stacked against me. As a result, I was seen as a rarity and was beginning to find my voice as a Latina female, living the balance of two worlds and the double standards that came along with it. I knew that there existed a lack of educated Latina women, so I vowed to support as many people as I could that have had similar struggles. Getting people out of predetermined tracks and removing all labels has been my mission and mentoring them into pathways, my goal. One of the ways that I empower women and support the education of underrepresented students is through education courses that I teach at the community college level. I am privileged to be able to reach out to a population that faces similar struggles and are working to have their voices heard through education. I am now a first-hand witness on how they struggle as mothers, wives, students and aspire to bridge that gap by being responsive and flexible with their needs.

Education has opened my eyes in positive ways but also has shed light on the system that has been set up to perpetuate inequities and the oppression of minorities. I am now becoming a transforming voice for my community; I concentrate on issues of social justice and pedagogies that liberate the mind. Issues of equity and diversity that were not always available for "someone like me" drive that passion for institutional change. Classrooms are more diverse than ever, and educators must be able to meet the demands of their student population and communities in order for students to know their true identities. I want to ensure that, in education, we stay away from deficit models and serve our students in a manner where we recognize that all students bring knowledge and curiosity, and where students recognize that their ancestors left a legacy filled with admirable contributions and that they 
may continue to thrive with pride. I have learned firsthand how the system oppresses people like me. Those invisible labels continue to determine something that we can all see, the lack of success for people of color. Structures that are built to educate continue to exclude and prevent my people from getting through their gates. We must have a commitment to our communities to bring what we have access to and share and create a path for change. We must commit to live our realities and use those experiences to create that necessary dialogue where norms will be challenged. Only then will we transform and become visible.

\section{The revolution is real and continues: The fight for institutional access for students of color}

Margarita Machado-Casas

Civil unrest and political instability brought me to the United States at the age of fourteen. Originally from Nicaragua, my family migrated once before to Panama, before coming to the United States. My life today remains closely tied to my lived experiences as an immigrant navigating this country. As an English language learner, and Afro-Latina I did not fit in schools. I was an outsider not only culturally, but also academically. I struggled to learn the dominant language, but quickly realized that roads are not available for those of us who are unwanted. So, I began to learn how to create my own path. After arriving in the US, my family settled in California where I earned a bachelor's and master's degrees. At some point I came to the realization that higher education was not made for people like me. In California, I worked as a bilingual teacher and I was a community activist who toiled to improve the lives of my students and their families. Teaching gave me insight into the disproportionately lower rates of graduation and lack of resources that were part of the realities my students were destined for, realizing how the system did not provide them with a chance. I began to question, what can I do about this? What can I do to eradicate the marginalization and destruction of our communities? During that time, I met Dr. Barbara Flores and others like Dr. Enrique Murillo who shed a light on the possibility of what my future could look like. Through mentorships I clung to, I began to release the stress and fear I was carrying because they provided me with a sense of security and hope. All of the dreams I shared with them, they received and returned them back to me with newfound possibilities -that is, mentorship on how to access higher education. I then took that knowledge and moved across the country to begin a doctoral degree, which I obtained at the University of North Carolina at Chapel Hill where I worked with newly arrived Latino immigrant families and was actively engaged with the community. I was one of two Latinas on my doctoral cohort and the only Afro-Latina. The experience was traumatic to say the least. I was devalued, discriminated against, and academically attacked. There I realized that racism was alive and well. That the very reason of my existence in the South and in a doctoral program was problematic and reason enough to hate me and take every possible step to make my experience miserable. So rather than the "impostor syndrome" this experience led me to feel the "robber syndrome" (Machado-Casas, 2015, p. 25), the way I was treated as if I was robbing the system. Every time I passed a class, there was another reason to marginalize or penalize me. As if I was taking away from those whom this higher education was really meant for. This led to trauma -which I had to release. But also learned that allies are important. My advisor Dr. George Noblit played a crucial role in making sure I stayed. He reminded me daily that I belonged there, that I had to release all I was carrying in order to receive and help my community as I always imagined. I graduated top of my class and got several awards for the impact of my research on immigration and education in the South. I then completed a post-doctoral fellowship in Latino education and mixed methodology, also at UNC-Chapel Hill. After contemplating many options, I decided to move to Texas because I wanted to teach in an HSI in 
order to work in a place where I could motivate minority students and mentor them in the process of becoming professionals. A planned short stay turned into twelve years teaching in Texas. To my surprise, Texas became home. I was able to find after several years a community of people outside of academia that helped me in transitioning the difficulties I encountered. Being a new tenure-track faculty member in a higher education institution is like entering a laberinto because the need to figure out the road(s) to get tenure is evident, but the way to get there is uncertain. New tenure-track "faculty of color are less likely to be fully integrated into the academic culture at higher education institutions" (Barret, 2005, p. 1) and thus, they may not be as likely to earn tenure or promotions at the same rate as their white colleagues. Latina academics often experience overt and covert forms of marginalization. For example, they may encounter racism, sexism, and classism, as well as self-doubt, the impostor syndrome, isolation, and invisibility (Achor \& Morales, 1990; De la Luz Reyes \& Halcon, 1988; Solórzano \& Yosso, 2001; Turner, 2002; Turner \& Myers, 2000). There I was able to get tenured and then a full professorship, I soon realized that many HSI enrolled students but did not serve students. It was often a conversation my colleagues and I had. I also realized the importance of working in a department that was committed to fighting institutional racism.

At that bilingual education department, I was able to revive Bilingual Education Student Organization (BESO). A group that was started by two women who became mentors, Dr. Ellen Riojas-Clark and Dr. Belinda Flores. Both of them played different roles in my life while in Texas. They released, received, returned to me and others so much knowledge, and I in turn did the same for others. BESO gave me life and purpose. I fought for my students and often became a defender for them. It was during this time that I realized that I had to release the truth to our students of color, release empowerment and hope. In order to receive the blessings of making pathways and helping others and returning this to our students and communities,
I worked toward creating pathways for our students of color and making access visible and possible. But I knew that so as to make institutional change within an oppressive system, I had to be present on the decision table. Going into administration was not something I was eager to do. Quite honestly, I was scared and even though I knew I could do it, and others encouraged me to take the leap, fear got in the way. But we cannot preach what we are not able to try and do. So remember that higher education was not made for us, in every sense of the word. And this was a revolution to create pathways for our students to gain access. That we need people at all levels. That leaders who fight for social justice, who can say "I have been there," who can give hope, who can serve as models are needed on the decision table in order for our students to make in this revolution towards access and social justice in the laberinto called higher education. With the intention of making an institutional change, we must act at all levels as we are fighting the very distance of oppression that led to our exclusion as communities of color, we are fighting systems that were not made for us. Now as a department chair I helped create a pathway program at the university level and I work daily on bringing awareness of the need to continue to work for access for bilingual, multilingual communities of color and in areas of high need. In this process, I'm in constant flux as I release truth and access. I also receive many things, from love to attacks, and I continue giving back to our communities the knowledge that I have gained and the power I have to create access for other students. It's critical to know that as educators, leaders, and people who have had the privilege to make it through the laberinto of higher education, graduation is not the end goal. And in reality, there may not ever be an end goal but rather a progression. We have to understand that in order for change to happen, we have to get to the decision table but also help others get there. As educational leaders that is part of the battle against institutional inequities and marginalization toward our students. 
We have to fight at all levels, as all levels have their own laberintos. Only by doing so, and making sure others get through the labyrinth, we release the truths about places that were not made for us, we receive and give back to our communities what was stolen from them: access. We all become fighters, and critical components in dismantling the labyrinth of higher education in order to hold the door open for others.

\section{Findings}

In this paper, we explore how the practice of testimonio writing offered us, as Latinx people navigating higher education, a spiritual labyrinth-like journey to reflect on our experiences. Testimoniando allowed each author to bear witness to their own and one another's experience releasing, receiving and returning to higher education with deeper purpose for sustainability in the field. Just as physically walking a labyrinth can lead to personal revelations, testimoniando through the metaphorical labyrinth of higher education offered deeper internal reflections and connections to the larger meanings of our struggles and our resiliency.

The first phase of testimoniando through el laberinto of higher education was releasing. For each participant, releasing painful memories and traumas related to higher education was important in order to reclaim our own narrative and sense of self. Before releasing, however, our painful truths needed to be centered in order to spiritually and emotionally release them to the earth, the universe or whatever higher power one ascribes to believing in via their personal spiritual practice. Centering these painful truths can often feel overwhelming, which makes acknowledging negative experiences, memories of discrimination or self-defeating thought, so difficult. However, if and when we do not face that pain, the stories are internalized and often morph into shame, guilt, inferiority complexes and impostor syndrome. Therefore, engaging in testimonio offered each of the authors the space to reflect back, name their struggles and reclaim their power, identities and experiences. The practice of releasing painful memories is a critical stage necessary for transformation and for communities of color to move beyond racialized, gendered and other forms of social traumas through conscientization (Freire, 2000) an in-depth understanding of the world, allowing us to understand social systems of oppression which lead to action.

After passing through the first stage of releasing by testimoniando through el laberinto of higher education, each participant was able to receive the larger lessons, epiphanies, guidance and clarity from their painful experiences. For example, receiving the larger lessons about the importance of critical mentorship, community, solidarity or emotional/physical/spiritual wellness led to clarity in relation to sustainability in higher education. These forms of clarity sometimes showed up as guidance in the symbolic form of salvavidas (lifeguards) while navigating the laberinto of higher education. For some, finding an organization that supported them was critical, for others it was people that encouraged them to keep moving forward. What all participants had in common was that receiving guidance or salvavidas in whatever form it manifested in, led to clarity, purpose, revival and empowerment.

In the third phase, returning from testimoniando through el laberinto of higher education, each author experienced a renewed sense of urgency and spiritual connection to their purpose within higher education. Testimoniando about navigating the laberinto of higher education allowed each of us to go back to ourselves, our communities, our students, our research and our respective positions as renewed, revived and re-inspired to thrive as a form of resistance. From returning and creating pathways, to practicing self/collective care, to holding leadership positions in academia, each of these responses to oppression required a deep sense of connection to their labor that resisted capitalist logics. In essence, higher education is designed to pit people against one another in the form of competition and ego-driven accolades, which is why navigating 
these spaces necessitates critical race and feminists praxis like testimonio in order to resist these logics and reimagine more liberating ways of being.

\section{Conclusion}

The diversity gap in higher education remains just as wide today as it has been for decades, so it is critical that people of color find pathways of support for themselves and future generations. Considering the uncertainties that first-generation academics experience when trying to navigate the laberinto of higher education, engaging in and with spiritual practices and spaces transform uncertainty into deeper purpose and clarity within the field. In essence, making it into higher education and sustaining oneself in academia has less to do with the mere representation of faculty of color and more to do with reclaiming and utilizing power to redistribute resources to communities of color that have been kept from them.

Feelings of incompetence within our respective disciplines and positions in the field are a byproduct of colonial standards and symptomatic of white supremacy which shapes the "ivory tower" and creates continual barriers for communities of color. Knowing this, engaging in testimonio allows for the political, ideological and spiritual clarity needed to resist the very tactics, practices, policies and structures that have and continue to perpetuate oppression.

Knowing how to navigate el laberinto of higher education is necessary, every barrier serves its purpose in our journeys of conscientization. Every emotional and visceral response we experience in higher education is also necessary to center as a place of inquiry even though, "emotion is not and rarely has been valued in academic life... [and] academics have been trained to ignore, mistrust and devalue emotion" (Brockbank \& McGill, 2007, p. 53).

The praxis of testimonio allows for the centering and release of social trauma experienced from navigating structural violence via higher education. It also allows for the receiving of guidance and clarity in myriad forms. Most importantly, testimonio allows for people of color at the margins of university institutions and academia to return empowered and reinvigorated to push a change. The toxic culture of production and competition in higher education can often leave little time for critical self and collective reflection, so testimonio in its very essence detoxes us from the harmful symptoms of academic life. Releasing that which has harmed us, receiving that which helps to heal us, and returning to the same positions with deeper purpose to reimagine what higher education can be is not only necessary, it is in fact, revolutionary.

\section{References}

Achor, S., \& Morales, A. (1990). Chicanas holding doctoral degrees: Social reproduction and cultural ecological approaches. Anthropology \& Education Quarterly, 21, 269-287.

Anderson, D. D., \& Shore, W. J. (2008). Ethical issues and concerns associated with mentoring undergraduate students. Ethics \& Behavior, 18(1), 1-25.

Anzaldúa, G. (1987). Borderlands: la frontera (Vol. 3). San Francisco: Aunt Lute.

Anzaldúa, G. (2009). The Gloria Anzaldúa Reader. Durham, NC: Duke University Press.

Astin, H. S., Antonio, A., Cress, C. M., \& Astin, A. W. (1997). Race and ethnicity in the American professoriate, 1995-96. Los Angeles: Higher Education Research Institute, Graduate School of Education \& Information Studies.

Artress, L. (1996). Walking a sacred path: Rediscovering the labyrinth as a spiritual practice. New York: Penguin. 
Barret, R. K. (2005). Cross-cultural mentoring for faculty of color. Washington, DC: American Council on Education Department Chair Online Resource Center, American Council on Education Department Leadership Project.

Bernal, D. D., Burciaga, R., \& Carmona, J. F. (Eds.). (2017). Chicana/Latina testimonios as pedagogical, methodological, and activist approaches to social justice. Abingdon: Routledge.

Bettez, S., Lopez, J., \& Machado-Casas, M. (2009). "Hermandad" (sisterhood): Latinas in Higher Education. In D. Cleveland \& C. Sleeter (Eds.), When "Minorities are strongly encouraged to Apply": Diversity and affirmative action in higher education. (pp. 23-34). New York: Peter Lang Publishing.

Brockbank, A., \& McGill, J. (2007). Facilitating reflective learning in higher education (2nd ed.). Buckingham, UK: SRHE/Open University Press.

Cleveland, D. (Ed.). (2009). When "minorities are strongly encouraged to apply": Diversity and affirmative action in higher education. New York: Peter Lang Publishing.

De la Luz Reyes, M., \& Halcon, J. J. (1998). Racism in academia: The old wolf revisited. Harvard Education Review, 58, 299-314.

Castillo, A. (1994). Massacre of the dreamer: Essays on Xicanisma. Albuquerque: University of New Mexico Press.

Cope-Watson, G., \& Betts, A. S. (2010). Confronting otherness: An e-conversation between doctoral students living with the Imposter Syndrome. Canadian Journal for New Scholars in Education/Revue canadienne des jeunes chercheures et chercheurs en éducation, 3(1).
Delgado Bernal, D. \& Villalpando, O. (2002). An Apartheid of Knowledge in Academia: The Struggle Over the "Legitimate" Knowledge of Faculty of Color. Equity \& Excellence in Education, 35(2), 169-180, DOI: 10.1080/713845282.

Ek, L. D., Cerecer, P. D. Q., Alanís, I., \& Rodríguez, M. A. (2010). "I don't belong here": Chicanas/Latinas at a Hispanic serving institution creating community through muxerista mentoring. Equity \& Excellence in Education, 43(4), 539-553.

Elenes, C. A. (2000). Chicana feminist narratives and the politics of the self. Frontiers: A Journal of Women Studies, 21(3), 105-123

Fish, S. (2002). Somebody back there didn't like me. Chronicle of Higher Education. Retrieved from http:// chronicle.com/jobs/2002/09/2002091301c.htm

Flores, J., \& Garcia, S. (2009). Latina testimonios: A reflexive, critical analysis of a 'Latina space' at a predominantly White campus. Race, Ethnicity and Education, 12(2), 155-172.

Forehand, R. L. (2008). The art and science of mentoring in psychology: A necessary practice to ensure our future. American Psychologist, 63(8), 744.

Freire, P. (2000). Pedagogy of the oppressed. New York: Continuum.

Freire, P. (2008). The "Banking" Concept of Education. In Bartholomae, David \& Anthony Petrosky, Ways of Reading (pp. 242-254), 8th ed. Boston: Bedford-St. Martin's.

Fuentes, E. H., \& Pérez, M. A. (2016). Our stories are our sanctuary: Testimonio as a sacred space of belonging. Association of Mexican American Educators Journal, 10(2), 6-13. 
Galvan, R. T. (2011). Chicana transborder vivencias and autoherteorias: Reflections from the field. Qualitative Inquiry, 17, 552-557.

García E., E., \& Curry-Rodríguez, J. E. (2000) The Education of Limited English Proficient Students in California Schools: An Assessment of the Influence of Proposition 227 in Selected Districts and Schools, Bilingual Research Journal, 24(1-2), 15-35.

Grande, S. (2000). American Indian geographies of identity and power: At the crossroads of indigena and mestizaje. Harvard Educational Review, 70(4), 467-498.

Guarino, C. M., \& Borden, V. M. (2017). Faculty service loads and gender: Are women taking care of the academic family? Research in Higher Education, 58(6), 672-694.

Hu, C., Thomas, K. M., \& Lance, C. E. (2008). Intentions to initiate mentoring relationships: Understanding the impact of race, proactivity, feelings of deprivation, and relationship roles. The Journal of Social Psychology, 148(6), 727-744.

Hurtado, S., Ruiz, A., \& Whang, H. (2012). Assessing students' social responsibility and civic learning. Association for Institutional Research. New Orleans.

Kaplan, K. (2009). Unmasking the imposter. Nature, 459, 468-469. DOI: 10.1038/nj7245-468a

Kaufman, G., \& Raphael, L. (1984). Relating to the self: Changing inner dialogue. Psychological Reports, 54(1), 239-250.

Kohli, R. (2008). Breaking the cycle of racism in the classroom: Critical race reflections from future teachers of color. Teacher Education Quarterly, 35(4), 177-188.
Love, H. (2019). Auditory Discrimination, Spelling and Reading with Bilingual and Monolingual Children. Journal of Developmental Reading, 6(3), 212-214. Retrieved March 24, 2020, from www.jstor.org/ stable/40015936

Laden, B. V. (2009). Faculty of color: Positive or negative experiences in the academy? When "minorities are strongly encouraged to apply". Diversity and affirmative action in higher education, D. Cleveland (Ed.). New York, NY: Peter Lang. 75-92.

Machado-Casas, M., Ruiz, E., Cantu, N. E. (2013). Women of color faculty testimonios and laberintos: Validating spaces for women of color faculty in higher education: Introduction to the special issue. Educational Foundations, Winter/Spring, 27(1-2), 3- 16.

Mawdsley, R. (1999). Collegiality as a factor in tenure decisions. Journal of Personnel Evaluation, 13, 167-177.

McFarland, J., Hussar, B., Zhang, J., Wang, X., Wang, K., Hein, S., Diliberti, M., Forrest Cataldi, E., Bullock Mann, F., \& Barmer, A. (2019). The Condition of Education 2019 (NCES 2019-144). U.S. Department of Education. Washington, DC: National Center for Education Statistics.

Moraga, C., \& Anzaldúa, G. (Eds.). (1981). This bridge called my back: Writings by radical women of color. Watertown, MA: Persephone Press.

Morales, E. (2018). LatinX: The new force in American politics and culture. New York: Verso Books.

Murillo, E. (2002). How does it feel to be a problem? "Disciplining" the transnational subject in the American south. In S. Wortham, E. Murillo \& E. Hamann (Eds), Education in the new Latino diaspora: Policy and the politics of identity. Westport, CT: Ablex. 
Nuñez-Janes, M., \& Robledo, A. (2009). Testimoniando: A Latina/Chicana critical feminist approach to racism in college. Chicana/Latina Studies: The Journal of Mujeres Activas en Letras y Cambio Social, 9(1), 72-102.

Paglis, L. L., Green, S. G., \& Bauer, T. N. (2006). Does adviser mentoring add value? A longitudinal study of mentoring and doctoral student outcomes. Research in Higher Education, 47(4), 451-476.

Pérez Huber, L., \& Cueva, B. M. (2012). Chicana/ Latina testimonios on effects and responses to microaggressions, Equity \& Excellence in Education, 45(3), 392-410

Ponjuan, L. (2011). Recruiting and retaining Latino faculty members: The missing piece to Latino student success. Education Digest, 78(5), (2013), 64-68.

Pour-Khorshid, F. (2018a). Cultivating sacred spaces: a racial affinity group approach to support critical educators of color. Teaching Education, 29(4), 318-329.

Pour-Khorshid, F. P. P. (2018). HELLA: A bay area critical racial affinity group committed to healing, empowerment, love, liberation, and action (Doctoral dissertation, UC Santa Cruz).

Pour-Khorshid, F. (2016). HELLA: Collective testimonio that speak to the healing, empowerment, love, liberation, and action embodied by social justice educators of color. Association of Mexican American Educators Journal, 10(2), 16-32.

Prieto, L. (2009). Conciencia con compromiso: Maestra perspectives on teaching in bilingual education classrooms. Unpublished dissertation. The University of Texas, Austin.

Rains, F. V. (1999). Dancing on the sharp edge of the sword: Women faculty of color in white academe.
In L. Christian-Smith \& K. Kellor (Eds.), Everyday knowledge and uncommon truths: Women of the academy, (pp. 147-174). Boulder, CO: Westview Press.

Rhoades-Catanach, S., \& Stout, D. (2000). Current practices in the external peer review process for promotion and tenure decisions. Journal of Accounting Education, 18, 171- 188.

Rich, S. \& Davis, L. (2007). Insights into the strategic ways in which two bilingual children in the early years seek to negotiate the competing demands on their identity in their home and school worlds. International Journal of Early Years Education, 15(1), 35-47.

Rodríguez, L. F., Mosqueda, E., Nava, P. E., \& Conchas, $G$. (2013). Reflecting on the institutional processes for college success: The experiences of four Chicanos in the context of inequality. Latino Studies, 11(3), 411-427.

Rodriguez, L. \& Oseguera, L. (2015). Our Deliberate Success: Recognizing What Works for Latina/o Students Across the Educational Pipeline. Journal of Hispanic Higher Education 2015, 14(2) 128-150.

Ruiz, E., Machado-Casas, M. (2013). An Academic Community of Hermandad: Research for the Educational Advancement of Latin@s (REAL), a Motivating Factor for First-Tier Tenure-Track Latina Faculty. Educational Foundations. Winter/Spring, $27(1-2), 49-63$

Saldivar-Hull, S. (2000). Feminism on the border: Chicana gender politics and literature. University of California Press.

Sandor, M. K., \& Froman, R. D. (2006). Exploring the effects of walking the labyrinth. Journal of Holistic Nursing, 24(2), 103-110. 
Santiago, D. A., \& Andrade, S. J. (2010). Emerging Hispanic-Serving Institutions (HS/s): Serving Latino Students. Washington, D.C.: Excelencia in Education.

Sensoy, Ö., \& DiAngelo, R. J. (2017). Is Everyone Really Equal?: An Introduction To Key Concepts In Social Justice Education. New York: Teachers College Press.

Sherman, R. 0. (2013). Imposter syndrome: When you feel like you're faking it. American Nurse Today, 8(5), 57-58.

Smith, L., Mao, S., Despande, A. (2015). "Talking Across Worlds": Classist Microaggressions in Higher Education. Journal of Poverty, 20(2): 1-25.

Solórzano, D. G. (2010, March). Using critical race theory and racial microaggressions to examine everyday racism. A keynote presentation to the University of California Santa Barbara, Multicultural Center's Race Matters Series. Santa Barbara, CA.

Solórzano, D. G., \& Yosso, T. (2001). Maintaining social justice hopes within academic realities: $A$ Freirian approach to critical race/lat. crit. pedagogy. Denver Law Review, 78, 595-621.

Sue, D. W., Capodilupo, C. M., Torino, G. C., Bucceri, J. M., Holder, A. M. B., Nadal, K. L., \& Esquilin, M. (2007). Racial microaggressions in everyday life: Implications for clinical practice. American Psychologist, 62(4), 271-286.
The Latina Feminist Group. (2001). Telling to live: Latina feminist testimonios. Durham, NC: Duke University Press.

Turner, C. S. V. (2002). Women of color in academe: Living with multiple marginality. The Journal of Higher Education, 73(1), 74-93.

Turner, C. S. V., \& Myers, S. L. Jr. (2000). Faculty of color in academe: Bittersweet success.

Upper Saddle River, NJ: Pearson Education.

Trueba, E. (2004). The new Americans: Immigrants and transnationals at work. New York: Rowman \& Littlefield.

Umbach, P. D. (2006). The contribution of faculty of color to undergraduate education. Research in higher education, 47(3), 317-345.

Urrieta Jr, L., Méndez, L., \& Rodríguez, E. (2015). “A moving target": a critical race analysis of Latina/o faculty experiences, perspectives, and reflections on the tenure and promotion process. International Journal of Qualitative Studies in Education, 28(10), 1149-1168.

Yúdice, G. (1991). Testimonio and postmodernism. Latin American Perspectives, 18(3), 15-31.

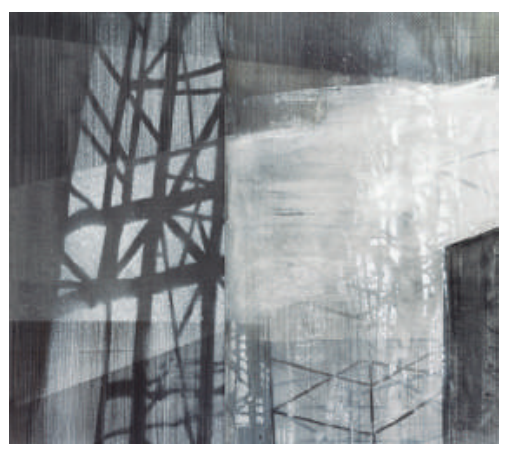

Amanda Knoweles

"Framework V"

Serigrafía, grafito y acrílico

$41.9 \times 36.8 \mathrm{~cm}$

2017

Seattle 

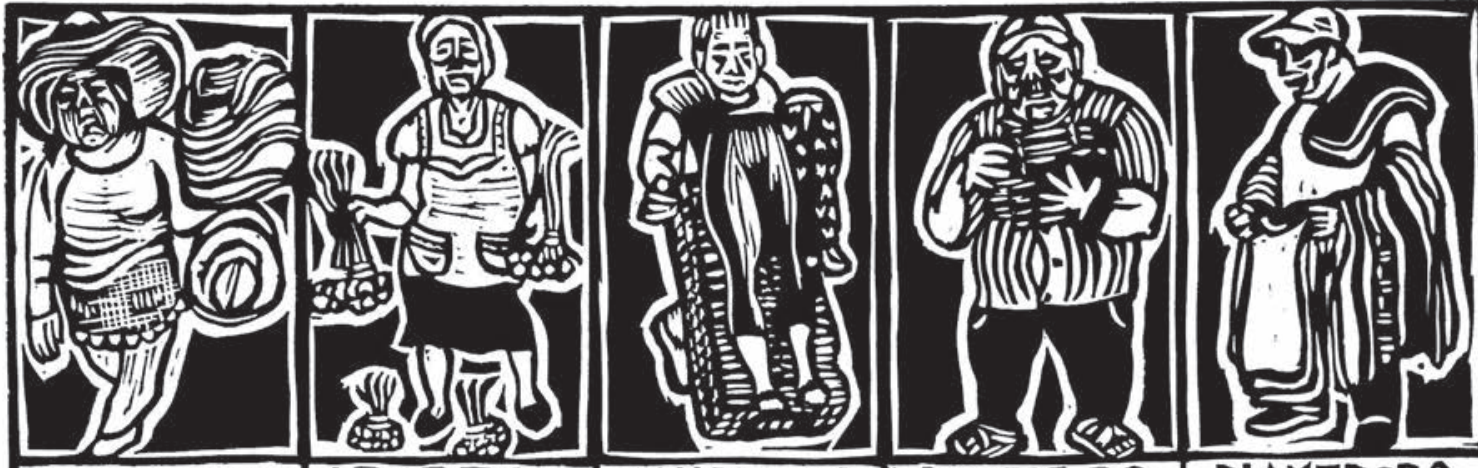

SOMERE RORA AJORERA MALLONERO
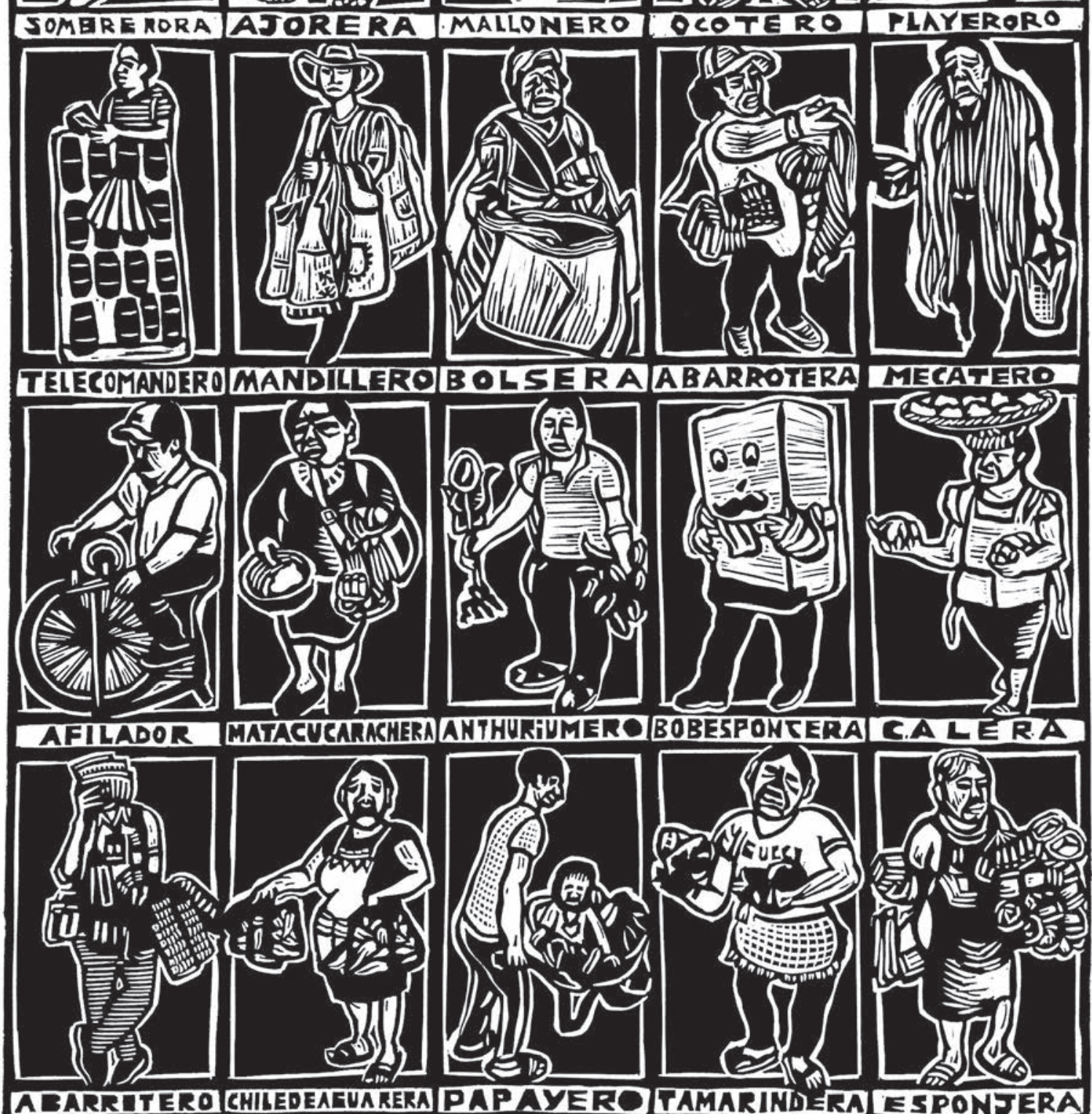

Misayo Tsutsui

"Domingo en Tlacolula" Linografía

$56 \times 37.8 \mathrm{~cm}$

2017

Oaxaca 


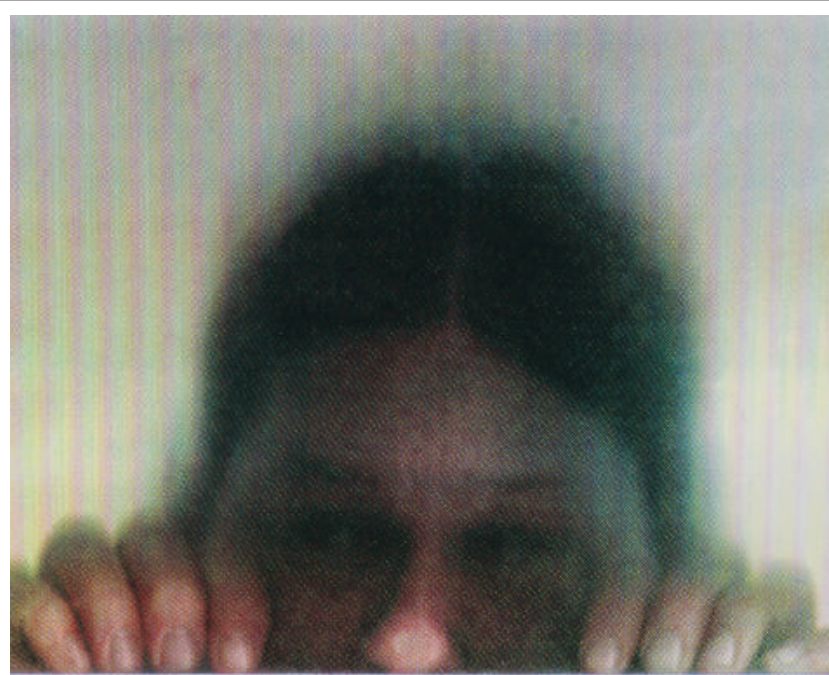

Brian Lane

"Hiding/Seeking"

Serigrafía (CMYK)

$61 \times 40.6 \mathrm{~cm}$

2018

Seattle

\section{hiding / SEEKING}

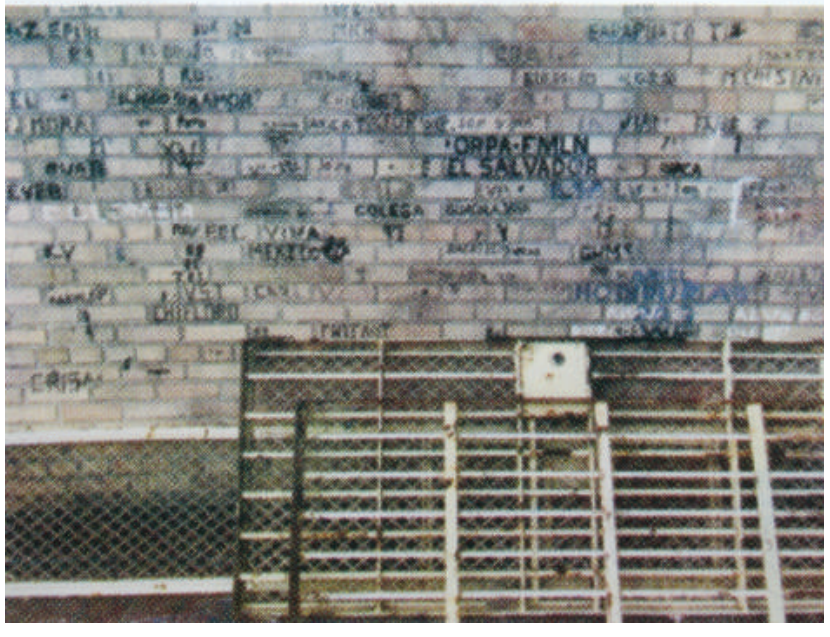

Fay Jones

"Woman in Container"

Monograbado

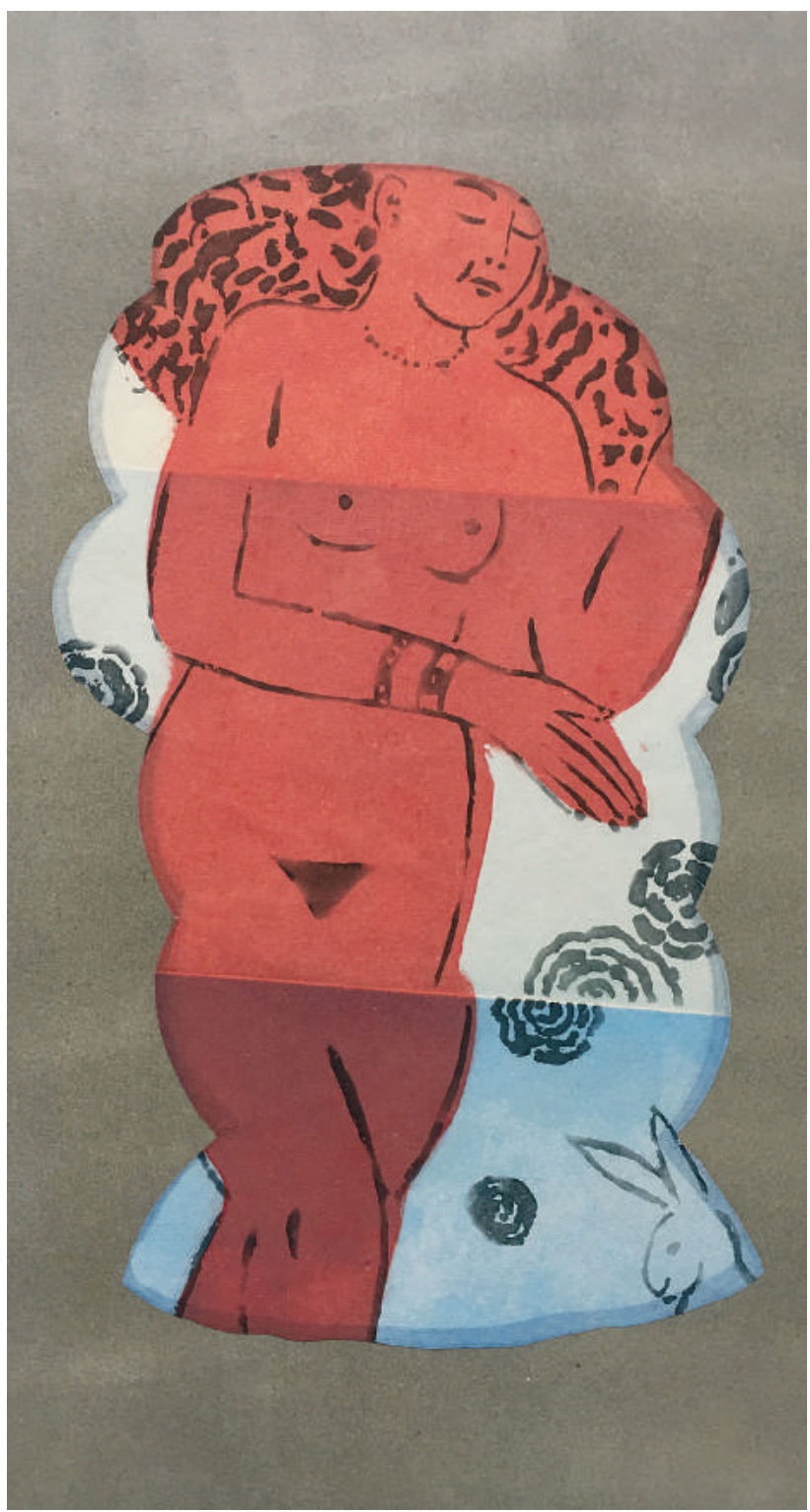

$67.5 \times 48.3 \mathrm{~cm}$

2008

Seattle 


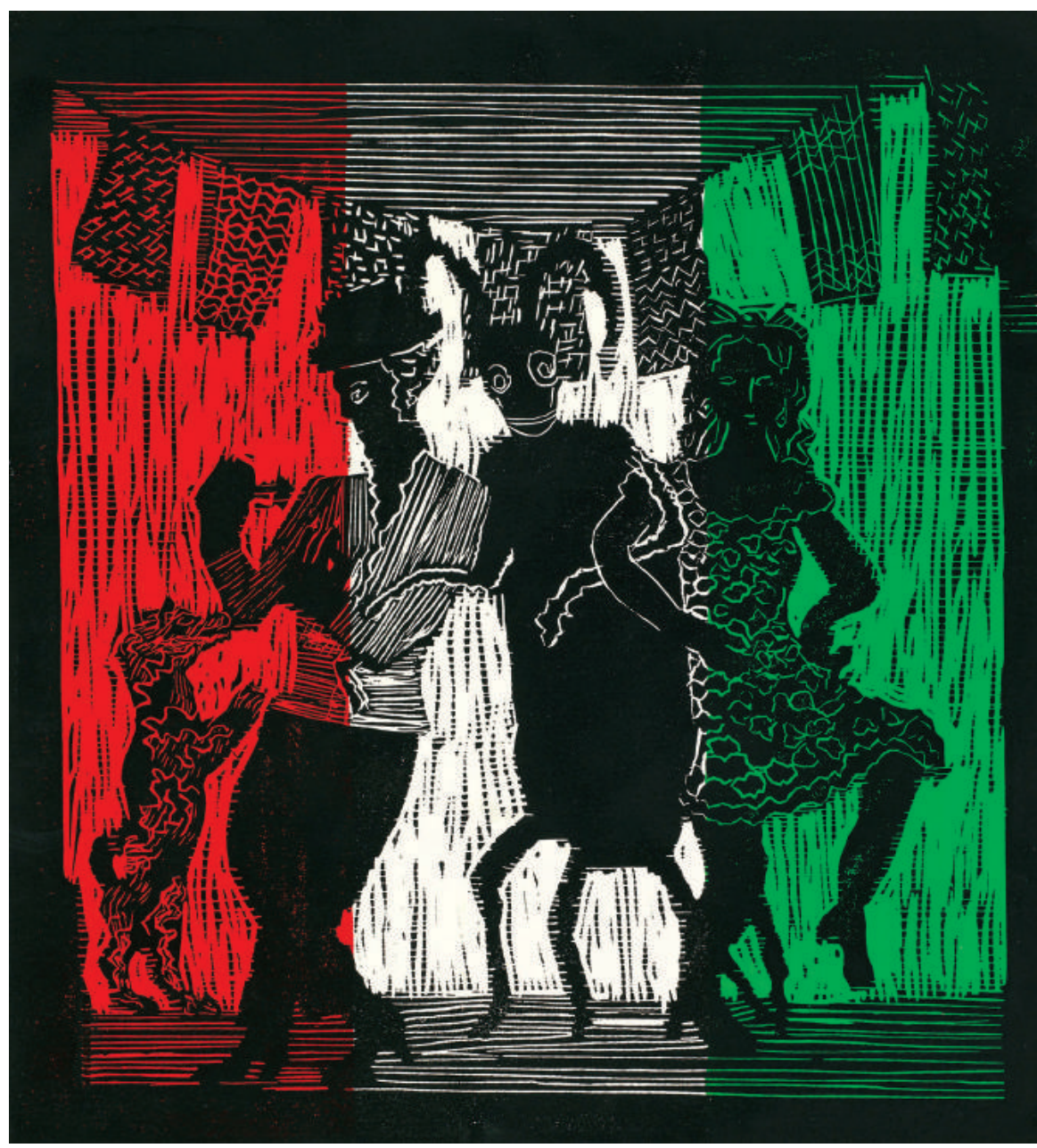

Elizabeth Sandvig

"La cucaracha"

Xilografía, gouache

$66 \times 50.3 \mathrm{~cm}$

2018

Seattle

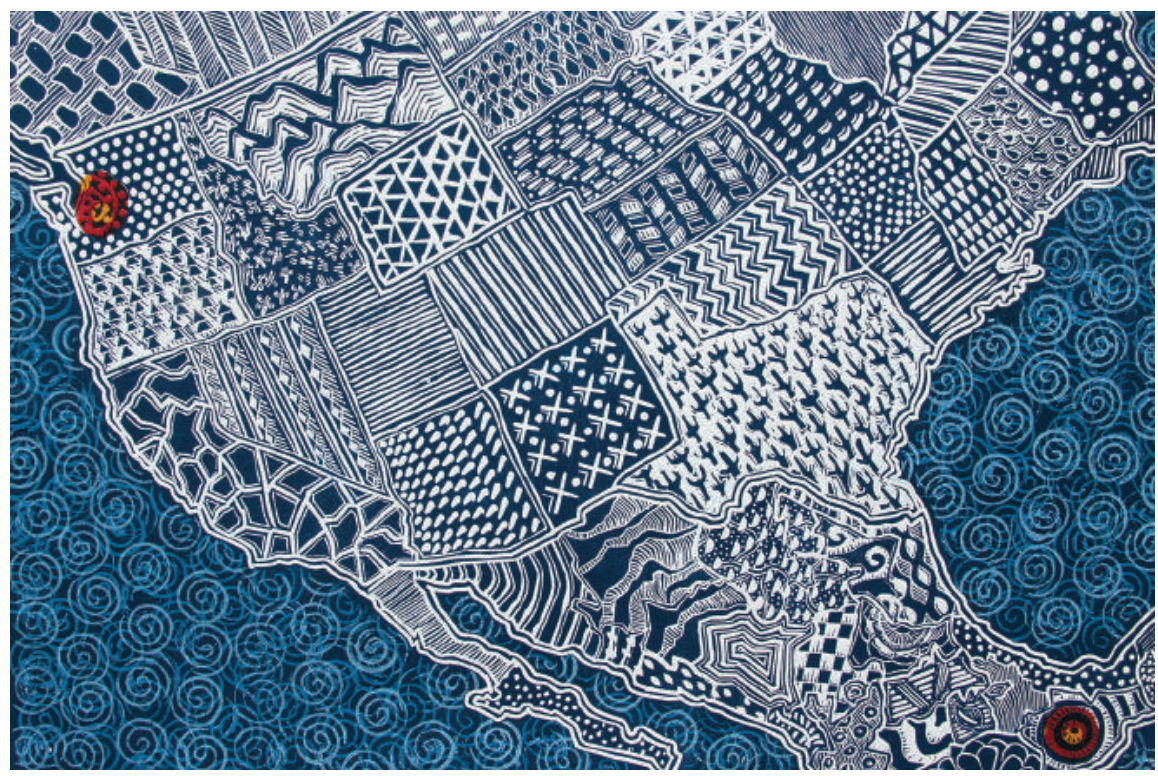

Laurie D Brown

"Beyond Borders"

Linografía, chine collé

$38.1 \times 57.1 \mathrm{~cm}$

2018

Seattle 


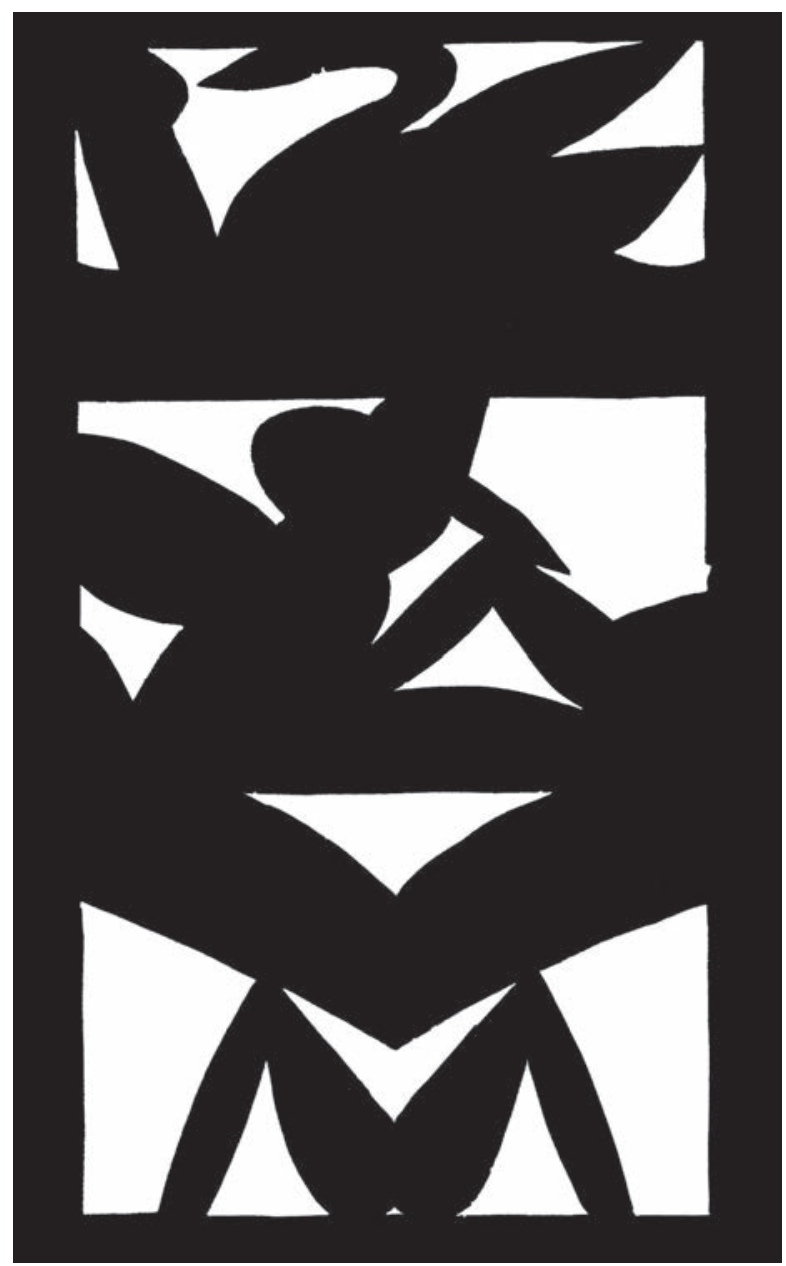

Michael C Spafford

"Leda and the Swan"

Xilografía

$66 \times 50.3 \mathrm{~cm}$

1998

Seattle

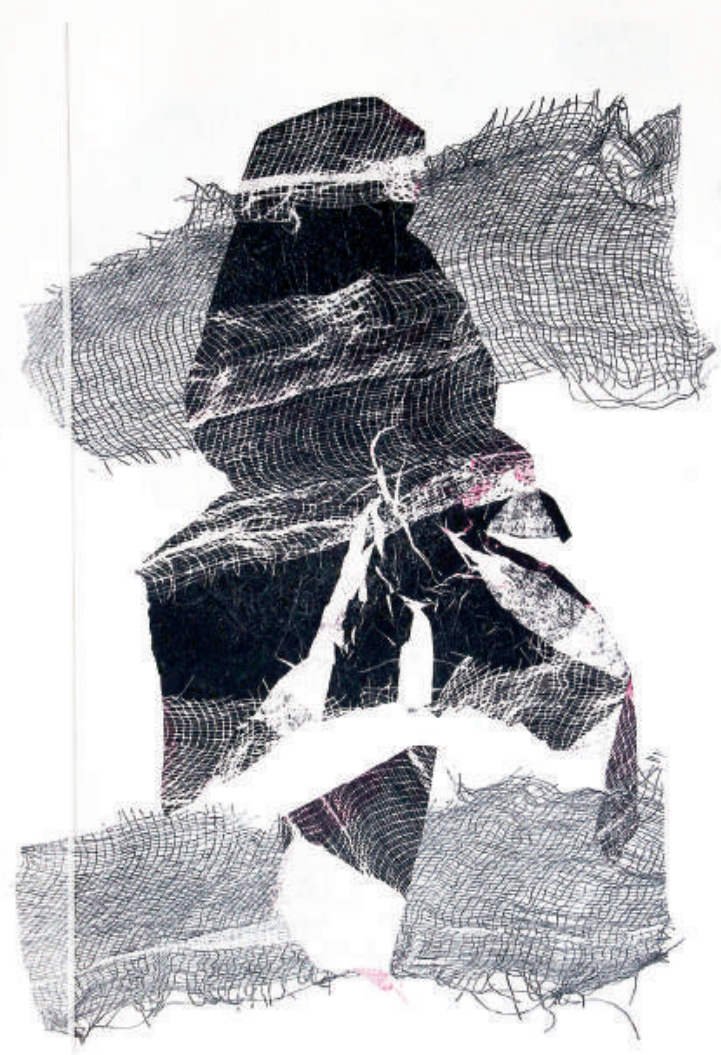

Tequio, mayo-agosto 2020, vol. 3, no. 9 